\title{
Patterns of innovation diffusion and technological competition in Portuguese manufacturing and service industries
}

\author{
Maria Fraga Oliveira Martins \\ Paulo Anciaes
}

ISEGI, Universidade Nova de Lisboa, Portugal

Published in International Review of Applied Economics 22 (3), 353-372.

\begin{abstract}
This paper uses data from the Portuguese Community Innovation Survey (CIS III) to analyse the interindustry heterogeneity in the diffusion of innovations and level of technological competition in Portuguese manufacturing and service industries. The industries are classified with reference to the relationship between the level of participation in innovation and the strategies of innovative firms. Methods of multivariate statistics are used to synthesize the data and to group the observations into subsets. Four distinctive innovation patterns are identified, defined along the following dimensions: output-orientation of innovation, importance of disembodied innovation, role of technologically advanced innovation and level of innovation opportunities. It is also found that high levels of technological competition tend to occur in sectors with relatively low dimension, productivity and overall investment.
\end{abstract}

Keywords: Innovation patterns, innovation diffusion, technological competition, CIS

\section{Introduction}

Empirical evidence suggests that there are significant inter-industry differences in the firms' innovation behaviour. This evidence is often understood as a sign of technological or economic determinism in innovation: different industries will follow different innovation patterns and these patterns depend on structural characteristics specific to each industry.

The study of sectoral-specific innovation patterns and its determinants is relevant for policy purposes, since the recognition of substantial differences in innovation patterns implies the necessity of introducing selective technological policies, suitable to the specific needs of each industry. General policies may not have an impact on the innovation behaviour of the firms in some industries. 
Innovation patterns at the industry level are often explained with reference to the concept of technological regimes (Nelson and Winter (1982), Winter 1984), according to which the firms' decision to innovate and subsequent innovation behaviour are determined by the environment in which they operate. Technological regimes have been characterized by aspects such as the level of technological opportunities (Klevorick et al 1995), continuity of innovation through time (Malerba and Orsenigo 2000, Cefis and Orsenigo 2001) and appropriability conditions of the innovation (Cohen et al (2002).

The evolution of innovation patterns in time may also follow a path characterized by certain industry-specific technological trajectories (Nelson and Winter (1977), Dosi (1982)). It is argued that firms in each industry tend to follow similar innovation strategies, as they have the same perceptions of the available alternatives. Several empirical studies have studied dimensions of sectoral technological trajectories, such as orientation towards product or process innovation (Pianta 2000, Nascia and Perani (2002), sources of information (Audretsch 1997), type of innovation input (Sellenthin and Hommen (2002), Veugelers and Cassiman (1999)) and degree and type of interaction between firms (Malerba 2002).

A stream of literature has focused on the classification of industries according to their innovation patterns. The primary source of reference for many studies is the work developed by Pavitt (Pavitt 1984, Pavitt et al 1989), who developed an industry taxonomy based on type of innovations (product $v v$ process innovation), objectives of $\mathrm{R} \& \mathrm{D}$, sources of information and appropriability mechanisms. Other studies have also classified industries according to a mix of indicators of technological regimes or technological trajectories. Recently, Castellacci (2004) systematized a series of dimensions related to both technological regimes and technological trajectories and developed an alternative to Pavitt's taxonomy.

Most of the recent studies on the identification of sectoral innovation patterns use formal statistical methods, first introduced by Evangelista (2000), where the industries are classified using clustering methods applied on a series of variables related to the firms' average innovation behaviour.

This paper attempts to identify for the Portuguese economy the inter-sectoral patterns of innovation with reference to two specific (and inter-related) dimensions: the level of innovation diffusion and the level of technological competition. These dimensions may be considered as a characteristic of the industries' technological regime (if understood as constraints to the firms' decision to innovate and to their innovative behaviour) or 
technological trajectory (if understood as explaining the firms' strategic choices in terms of innovation). Either way, it is expected that the relations between the levels of innovation diffusion and technological competition in an industry and the behaviour of the firms that innovate will follow some patterns. The aim is to classify the industries according to these innovation patterns.

The second objective of this study is to investigate the relations between innovation diffusion, technological competition and innovation environment. The innovation environment of an industry is defined as the set of conditions that firms face when deciding to innovate or engaging in innovation activities. It is assumed that the innovation environment can be assessed by the firms' perceived obstacles to innovation and the industries' structural characteristics.

The study considers both manufacturing and services in the same framework of analysis, in order to test whether there are distinctive patterns of innovation in those industries, given the increased opportunities for introduction of information technologies in services during the last decade (Coombs and Miles (2000)).

The paper proceeds as follows: Section 2 explains the conceptual framework used in the study and Section 3 introduces the data and methods used in the empirical analysis. Section 4 studies the inter-sectoral differences in innovation diffusion and technological competition in Portuguese industries. Section 5 looks into the relationships between innovation patterns, obstacles to innovation and structural characteristics of the industry. Section 6 is a discussion of some limitations of the analysis conducted and Section 7 concludes the paper and discusses some policy implications of the results found.

\section{Conceptual framework}

Innovation has been traditionally regarded as a linear process, where firms invest in research and development (R\&D) in order to generate knowledge to create new products, which are patented and introduced in the market.

This perspective is being largely abandoned, based on the recognition that many innovations do not originate on investments in $R \& D$ or are not aimed at the creation of new products. Also, many innovations are not patented, especially in the service industries (Evangelista and Sirilli 1995). Furthermore, innovation effort is not always effective in terms of creation of innovation output (Klomp 2001). The formulation of innovation policies thus requires a 
greater insight on the firms' innovation behaviour, by distinguishing between innovation inputs and outputs and by looking into the innovation process itself, that is, the way the innovation activities are organized in order to generate innovation output. It is nowadays accepted that the innovation process is a complex phenomenon, featuring many linkages from inputs to outputs and from the R\&D department to other departments in the firm (Kline and Rosenberg 1986).

The conceptual framework used in this study (Figure 1) considers the firms' innovation strategies (the set of innovation inputs, innovation processes and innovation outputs) together with the firms' decision to innovate and the sectoral determinants of both.

Figure 1: Framework of analysis

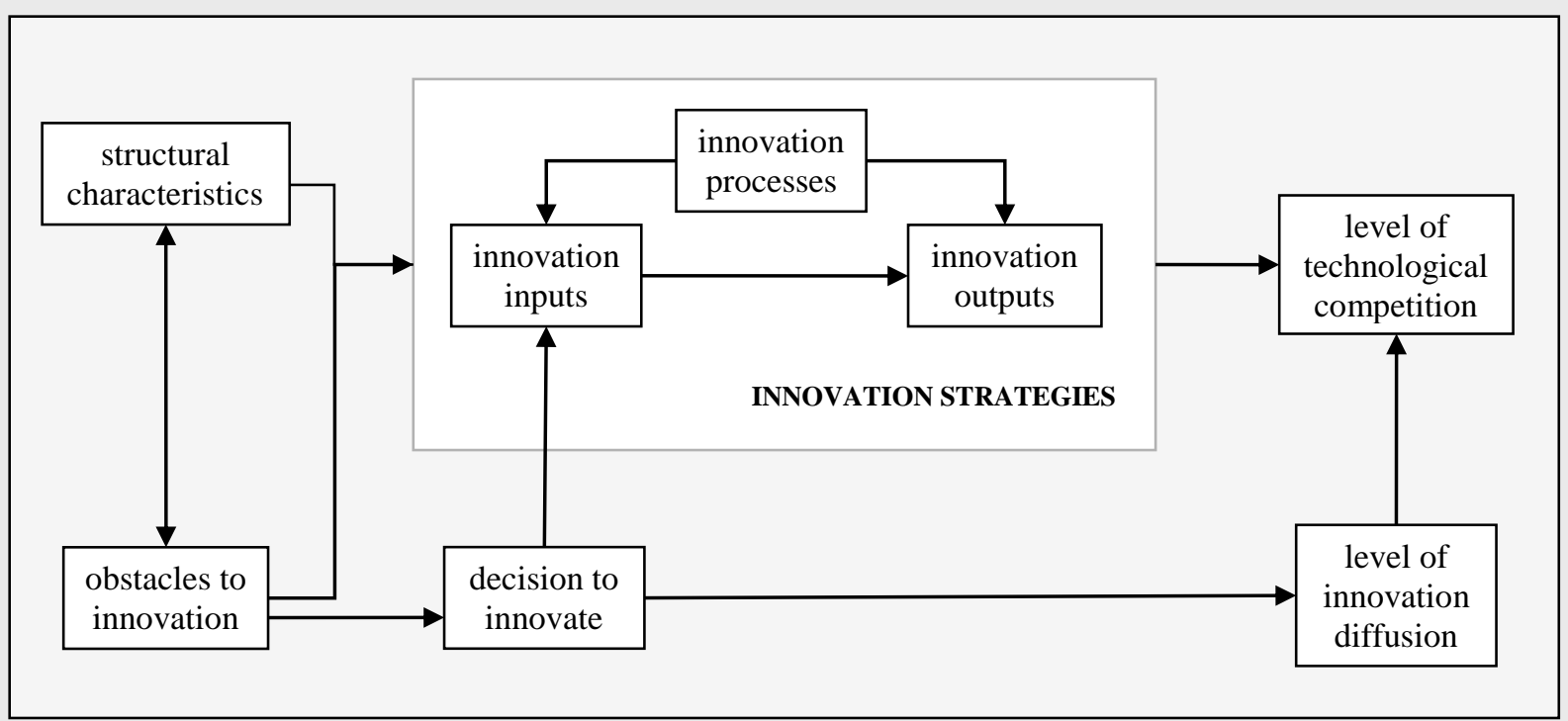

In each sector, the firms' decision to innovate depends on the perceived obstacles to innovation. The objective of the firms that innovate is to use innovation inputs (R\&D expenditure and others) and create innovation outputs (new products or new processes). The use of inputs is characterized by a set of processes (such as funding, cooperation or organizational changes). The generation of innovation outputs is also accompanied by a series of related processes (such as the protection of innovation).

The innovative firms' strategies depend on the perceived obstacles to innovation and also on the structural characteristics of the sector. Both are possibly inter-related.

The level of innovation diffusion in a given industry is defined by the percentage of firms that innovate. The level of innovation diffusion and the type of innovation strategies of the innovative firms define in turn the level of technological competition in the industry. 


\section{Data and method}

The data used in this study is taken from the Portuguese Community Innovation Survey (CIS III), covering the period 1998-2000. The CIS is a survey on firms' innovative behaviour which is carried out throughout the whole European Union using a harmonized questionnaire. The Portuguese CIS III was based on a stratified random sample of 1875 firms, out of a population of 23938 firms with 10 or more employees. The stratification is based on firm size and sector. However, the sample includes all firms with more than 200 employees. The dataset used in this study is aggregated at industry level, covering 38 sectors.

The information extracted from the CIS data is consistent with the directions for the collection and interpretation of innovation information defined in the framework of the OECD's Directorate for Science, Technology and Industry that led to the so-called "Oslo manual" (OECD 1996). The focus of the survey is to capture directly from the subjects of innovation (the firms) multiple dimensions of the innovation behaviour, thus providing wide range of information for national and EU technology and innovation policies.

The CIS survey is suitable for the analysis of our research question since it provides information on both the firms' decision to innovate and the behaviour of the innovative firms. For both innovators and non-innovators, information is also available on the perceived obstacles to innovation.

This survey distinguishes between innovation input and innovation output. On the input side, it acknowledges the existence of other innovation activities besides expenditure in R\&D, such as the acquisition of machinery and equipment, external knowledge acquisition and expenditures in training, marketing and design. On the output side, innovation is assessed not only by the number of patents applied or hold by the firm but also from the introduction of processes and products new to the firm.

A further advantage of the CIS data is the inclusion of information about the innovation processes, such as financing methods, cooperation arrangements, structural and management changes, sources of knowledge and ways of protection of innovation (where besides patents, a variety of strategic methods of protection are considered, such as time lead, secrecy and complexity of design).

The choice of variables to include in the study is based on the conceptual framework described in the last section. Information on the total sectoral innovation expenditure is not 
considered, since the analysis is not focused on innovation intensity but either on the firms' decision to innovate and type of innovation strategy. Also, information on the economic effects of innovation is not included, since it is not a dimension that is under direct control of the firm.

The selected indicators on innovation inputs, innovation processes and innovation outputs are first synthesized by factor analysis. The principal components are interpreted as dimensions of the firms' decisions to innovate and innovation behaviour and are used in a cluster analysis to identify different, homogeneous and mutually-exclusive sectoral patterns of innovation diffusion and technological competition. These clusters are then interpreted and characterized in terms of the principal components and the original variables.

In a second stage, the consistency of the innovation patterns found is tested against other CIS data not used in the clustering procedure: variables related to the sectoral structural characteristics and perceived obstacles to innovation. A factor analysis is performed on these new set of variables, in order to disentangle the associations that may exist between some of the indicators. The factors obtained are identified as different dimensions of each industry's innovation environment and then used to characterize the clusters of innovation patterns. Finally, the sectors are once more clustered, according to the factors related to the innovation environments and the resulting cluster membership is compared with the one obtained for the clustering of innovation patterns.

\section{Patterns of innovation diffusion and technological competition}

\subsection{Variables}

A series of indicators were calculated from the information available on the CIS III dataset:

a) Variables on the innovation inputs: expenditure in intramural $R \& D$ and expenditure in acquisition of machinery and equipment as a share of the total sectoral innovation expenditure.

b) Variables on the innovation processes with impact on innovation inputs: percentage of firms in the industry receiving public funding from the European Union; percentage of firms that have been cooperating in innovation projects; percentage of firms indicating as very important sources of knowledge sources from within the firm, sources from customers, sources from universities and sources from competitors; percentage of firms 
that have implemented new corporate strategies, advanced management techniques, changed organizational structures and changes in the products' aesthetic appearance.

c) Variables on innovation outputs: percentage of firms in the industry that have introduced into the market a new or improved product, sectoral turnover due to new or improved products as a share of total sectoral turnover, percentage of firms that have introduced a new or improved process.

d) Variables on the innovation processes with impact on innovation outputs: turnover covered by patent application as a proportion of total sectoral turnover, percentage of firms in the industry reporting protection of innovations through complexity of design and through long-time advantage.

The analysis is based in relative values, in order to isolate the influence of the number of firms and sectoral total innovation intensity (i.e., the total innovation expenditure) in the industries' innovation patterns. In particular, the percentages of firms in an industry engaging in product and process innovation are understood as the probabilities of engaging in product and process innovation for a given firm in that industry.

The introduction of products new to the firm was preferred to the introduction of products new to the market as an indicator of innovation output, since the focus of analysis is on the innovation from the firms' perspective, that is, on the decision of a firm to compete with other innovative firms in the market.

Also, the sectoral turnover covered by patents was preferred to the percentage of patent holders in the sector because the former is more suitable to evaluate the overall protection of the set of innovative firms in the sector from the non-innovative firms, that is, the protection from the potential technological competitors.

Three industries were excluded from the analysis, due to the small number of firms (Mining of Metal Ores, Tobacco) or because there was no product innovators (Research and Development).

\subsection{Factor analysis}

A factor analysis was performed on the set of variables selected, in order to reduce the large number of indicators to a smaller set of uncorrelated indicators that explain most of the variance in the sample. Out of the 18 variables, four major principal components were 
extracted, using the rule of retaining those components whose eigenvalues are higher than 1 (Kaiser 1958). In order to facilitate their interpretation, a rotated factor matrix was then created, using Orthogonal Varimax with Kaiser normalization. The results are presented in Table 1.

Table 1: Innovation patterns (Factor analysis)

\begin{tabular}{|c|c|c|c|c|c|c|}
\hline & $\begin{array}{c}\text { Factor } 1 \\
\text { (output-or.) }\end{array}$ & $\begin{array}{c}\text { Factor } 2 \\
\text { (disembodied) }\end{array}$ & $\begin{array}{l}\text { Factor } 3 \\
\text { (adv.proc.) }\end{array}$ & $\begin{array}{c}\begin{array}{c}\text { Factor } 4 \\
\text { (opportunities) }\end{array} \\
\end{array}$ & KMO & Comm. \\
\hline Exp. R\&D / total innovation exp. & 0,38 & 0,77 & 0,14 & $-0,02$ & 0.79 & 0.75 \\
\hline Exp. machinery / total innovation exp. & $-0,33$ & $-0,49$ & $-0,17$ & 0,25 & 0.58 & 0.39 \\
\hline EU funding & $-0,18$ & $-0,03$ & 0,13 & 0,83 & 0.55 & 0.74 \\
\hline Cooperation & 0,82 & 0,33 & $-0,07$ & $-0,16$ & 0.83 & 0.81 \\
\hline Sources: within firm & 0,17 & 0,7 & 0 & 0,26 & 0.59 & 0.59 \\
\hline Sources: customers & $-0,13$ & 0,13 & 0,77 & 0,04 & 0.35 & 0.63 \\
\hline Sources: universities & $-0,1$ & 0,07 & 0,61 & 0,29 & 0.65 & 0.47 \\
\hline Sources: competitors & $-0,08$ & 0,15 & 0,76 & 0 & 0.55 & 0.61 \\
\hline New corporate strategies & 0,91 & 0,18 & $-0,07$ & $-0,04$ & 0.76 & 0.86 \\
\hline Advanced management techniques & 0,88 & 0,28 & $-0,19$ & 0,05 & 0.73 & 0.88 \\
\hline New organizational structures & 0,73 & 0,3 & $-0,22$ & 0,2 & 0.83 & 0.71 \\
\hline Aesthetic appearance & 0,56 & $-0,53$ & 0,34 & 0,22 & 0.3 & 0.75 \\
\hline Product innovators & 0,83 & 0,19 & $-0,15$ & 0,05 & 0.93 & 0.74 \\
\hline Turnover new products /total turnover & 0,48 & 0,1 & $-0,04$ & 0,73 & 0.65 & 0.78 \\
\hline Process innovators & 0,54 & 0,23 & $-0,61$ & $-0,06$ & 0.63 & 0.73 \\
\hline Patent turnover / total turnover & 0,05 & $-0,19$ & 0,59 & $-0,17$ & 0.39 & 0.32 \\
\hline Protection: complexity of design & 0,45 & 0,79 & $-0,03$ & 0,01 & 0.68 & 0.82 \\
\hline Protection: long term advantage & 0,67 & 0,62 & 0,02 & $-0,13$ & 0.76 & 0.84 \\
\hline Eigenvalue & 6.8 & 2.47 & 1.75 & 1.4 & & \\
\hline Proportion of variance explained & 0.38 & 0.14 & 0.1 & 0.08 & & \\
\hline Cumul. prop. of variance explained & 0.38 & 0.51 & 0.61 & 0.69 & & \\
\hline
\end{tabular}

The four principal components explain $69 \%$ of the variance in the sample. The KaiserMeyer-Olkin measure of sampling adequacy (KMO) is 0.7 , which suggests that the correlation matrix is appropriate for factoring. The KMO for individual variables ${ }^{1}$ is also acceptable for most variables, as are the values of their communalities ${ }^{2}$.

Factor 1 is the component that explains most of the variance in the sample (38\%). This component has high factor loadings on the percentage of product innovators, the percentage of firms where structural changes have occurred, the percentage of firms co-operating in innovation and the percentage of firms protecting innovation through long term advantage. The percentage of process innovators is also correlated with this factor. 
The associations between the variables in this principal component confirm empirical evidence that successful product innovation require a set of structural changes in the firm (Kleinknecht and Oostendorp (2002). Also, cooperation between firms seems to be a key to the diffusion of innovation in an industry, or in other words, product innovation is a collective effort. Overall, this factor seems to be related to output-oriented innovation, that is, innovation less focused in the production of quality innovation input than in generating successful results (innovations).

The second factor explains $14 \%$ of the variance and has a high negative loading on the share of expenditure on machinery and equipment and high positive loadings on the share of R\&D expenditure, importance of sources of knowledge within the firm and strategic protection of the innovation (through complexity of design or long term advantage). The factor can be interpreted as a measure of the level of disembodied innovation. This kind of innovation is developed mostly within the firm and aims at the production of knowledge (thus implying strategic protection of the resulting output). The negative correlation found between share of expenditure in $R \& D$ and share of expenditure in machinery is consistent with most of previous results (e.g. Evangelista 1999, Veugelers and Cassiman (1999) and reflects the dichotomy "Make" $v$ "Buy" in the choices of innovation inputs 3 .

This component does not show high factor loadings on any of the indicators on innovation output. This result suggests an absence of strong correlation between innovation output and R\&D, which may confirm the obsolescence of the traditional notion of innovation originating solely in $R \& D$ expenditure. However, the result may also be explained by the fact that the generation of innovation output in a small, open and technologically lagging economy, such as Portugal, tends to rely on technological spillovers from other countries, mostly of the embodied kind.

The third factor captures $10 \%$ of the variance and shows a high negative loading on the proportion of process innovators and high positive loadings on the share of turnover covered by patents and the proportion of firms considering customers, competitors and universities as very important sources of knowledge. These results mean that the proportion of process innovators is inversely related to the formal protection of the innovations achieved by the firms that innovated. In addition, these firms rely on scientific sources of knowledge for their innovation activities and are aware of knowledge produced by competitors. This factor seems to be related to a notion of advanced process innovation, characterized by a high level of 
technological complexity and high level of technological competition among the innovators: firms aim at achieving technological leadership by innovating ahead of other firms, and try to secure the benefits of that leadership by protecting their innovations with patents.

Finally, factor 4 explains $8 \%$ of the variance and contains the turnover of new products as a share of total turnover and the indicator of level of EU funding. The association between these two variables suggests that this component is related to the level of innovation opportunities for the firms in each sector. The possibility of EU funding facilitates the organization of innovation effort, thus measuring the level of opportunities in terms of innovation input. The sales from new products as a share of total turnover can be interpreted as a proxy for the possibility of market diffusion of the innovation, which is the end-point of the innovation process. In that sense, this indicator measures the level of opportunities in terms of innovation output.

\subsection{Cluster analysis}

A cluster analysis using a non-hierarchical method (K-means) was performed on the scores of the four factors extracted. Preliminary performances of the cluster algorithms identified some outliers in the dataset (Office Machinery and Computers, Water Distribution and Rubber and Plastics). These are sectors showing extreme values for some variables and were excluded from further analysis 4 .

After the removal of the outliers, a solution with 4 clusters was chosen. This was based on the interpretability of the clusters in terms of membership; on the differences of the clusters means (indicators of inter-cluster heterogeneity) and on the clusters' standard deviations (indicators of intra-cluster heterogeneity). Cluster memberships are given in Table 2 and cluster characteristics are given in Table 3 and represented in Figure 2.

Table 2: Innovation patterns (cluster membership)

\begin{tabular}{cc}
\hline & Sectors \\
\hline $\begin{array}{c}\text { Cluster 1 } \\
\text { (n-comp. proc.) }\end{array}$ & $\begin{array}{c}\text { Other mining, Food and beverages, Textiles, Pulp and paper, Publishing and printing, Non- } \\
\text { metallic minerals, Basic metals, Machinery and equipment, Electricity and gas supply, } \\
\text { Recycling, Wholesale, Land transport, Water transport, Transport-related and travel, Finance- } \\
\text { related, Other business activities }\end{array}$ \\
\hline $\begin{array}{c}\text { Cluster } 2 \\
\text { (non-comp.) }\end{array}$ & Air transport, Post and Telecommunications, Financial intermediation, Insurance \\
\hline $\begin{array}{c}\text { Cluster 3 } \\
\text { (output-comp.) }\end{array}$ & $\begin{array}{c}\text { Chemicals, Fabricated metals, Electrical machinery, Motor vehicles, Furniture, Computer- } \\
\text { related activities. }\end{array}$ \\
\hline $\begin{array}{c}\text { Cluster 4 } \\
\text { (input-comp) }\end{array}$ & $\begin{array}{r}\text { Wearing apparel, Leather and footwear, Wood and Cork, Radio/TV and telecommunication } \\
\text { equipment, Medical and precision instruments, Other transport equipment }\end{array}$ \\
\hline
\end{tabular}


Table 3: Innovation patterns (cluster characterization)

\begin{tabular}{|c|c|c|c|c|c|}
\hline & $\begin{array}{c}\text { All } 35 \\
\text { sectors }\end{array}$ & $\begin{array}{c}\text { Cluster } 1 \\
\text { (n-comp proc) }\end{array}$ & $\begin{array}{c}\text { Cluster } 2 \\
\text { (n-comp) }\end{array}$ & $\begin{array}{c}\text { Cluster } 3 \\
\text { (output-comp) }\end{array}$ & $\begin{array}{c}\text { Cluster } 4 \\
\text { (input-comp) }\end{array}$ \\
\hline \multirow{2}{*}{ Factor 1: Output-oriented innovation } & \multirow{2}{*}{0} & -0.56 & 1.57 & 0.56 & -0.65 \\
\hline & & $(0.52)$ & $(0.89)$ & $(0.6)$ & $(0.5)$ \\
\hline \multirow{2}{*}{ Factor 2: Disembodied innovation } & \multirow{2}{*}{0} & -0.11 & -0.6 & .0 .34 & 0.55 \\
\hline & & $(0.57)$ & $(0.71)$ & $(0.54)$ & $(0.6)$ \\
\hline \multirow{2}{*}{ Factor 3: Advanced process innovation } & \multirow{2}{*}{0} & -0.53 & -0.48 & 0.42 & 1.34 \\
\hline & & $(0.52)$ & $(0.61)$ & $(0.33)$ & $(0.99)$ \\
\hline \multirow{2}{*}{ Factor 4: Innovation opportunities } & \multirow{2}{*}{0} & -0.21 & 0.9 & 0.54 & 0.17 \\
\hline & & $(0.5)$ & $(0.19)$ & $(0.63)$ & $(0.36)$ \\
\hline Exp. R\&D / total innovation exp. & 0.13 & 0.07 & 0.1 & 0.2 & 0.18 \\
\hline Exp. machinery / total innovation exp. & 0.56 & 0.64 & 0.45 & 0.58 & 0.45 \\
\hline EU funding & 0.20 & 0.17 & 0.01 & 0.27 & 0.28 \\
\hline Cooperation & 0.23 & 0.13 & 0.53 & 0.25 & 0.2 \\
\hline Sources: within firm & 0.45 & 0.43 & 0.45 & 0.38 & 0.49 \\
\hline Sources: customers & 0.21 & 0.15 & 0.09 & 0.3 & 0.39 \\
\hline Sources: universities & 0.04 & 0.02 & 0.01 & 0.02 & 0.12 \\
\hline Sources: competitors & 0.08 & 0.04 & 0.06 & 0.09 & 0.19 \\
\hline New corporate strategies & 0.37 & 0.27 & 0.65 & 0.43 & 0.27 \\
\hline Advanced management techniques & 0.33 & 0.25 & 0.56 & 0.35 & 0.22 \\
\hline New organizational structures & 0.43 & 0.37 & 0.57 & 0.52 & 0.28 \\
\hline Aesthetic appearance & 0.25 & 0.2 & 0.36 & 0.38 & 0.22 \\
\hline Product innovators & 0.37 & 0.26 & 0.69 & 0.45 & 0.23 \\
\hline Turnover new products /total turnover & 0.18 & 0.1 & 0.16 & 0.31 & 0.15 \\
\hline Process innovators & 0.43 & 0.46 & 0.66 & 0.38 & 0.25 \\
\hline Patent turnover / total turnover & 0.02 & 0.01 & 0 & 0.02 & 0.04 \\
\hline Protection: complexity of design & 0.10 & 0.05 & 0.1 & 0.11 & 0.09 \\
\hline Protection: long term advantage & 0.17 & 0.11 & 0.27 & 0.21 & 0.13 \\
\hline
\end{tabular}

Mean values and standard deviations (in brackets) 
Figure 2: Innovation patterns (cluster characterization)

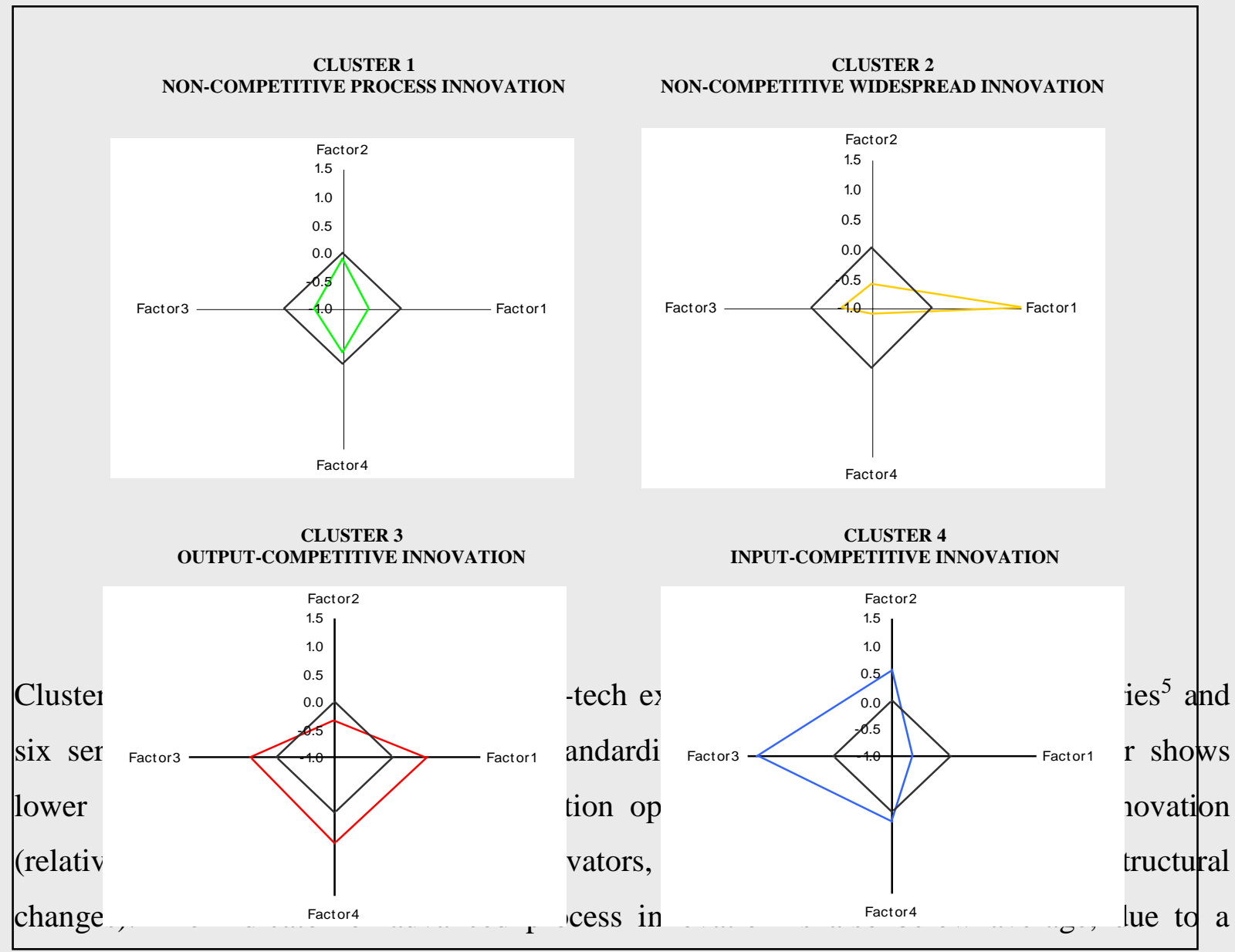

relatively high number of process innovators.

There is a slight tendency in the sectors in this Cluster for embodied forms of innovation, with above average levels of relative expenditure in machinery and equipment and below average levels of expenditure in $R \& D$ and strategic means of protection of innovation.

This cluster can be labelled non-competitive process innovation, since the high proportion of process innovators is not associated with clear strategies to gain and secure innovation advantage (as measured by use of internal R\&D and sources of knowledge from customers, universities and competitors) or to protect the benefits from innovation (either with formal or strategic methods).

In other words, although process innovation may be implemented in order to strengthen the firms' position in face of competition in the market for their products, there is no evidence that firms in these sectors are active in competing for the means that allow that competition, that is, competing for innovation advantage. The firms may compete through innovation but not in innovation. 
Cluster 2 contains four sectors from the service industries. This cluster shows a highly aboveaverage value for the indicator of output-oriented innovation, due to a very large proportion of product innovators ${ }^{6}$, firms that implemented structural changes and firms involved in cooperation. On the other hand, the importance of advanced process innovation is small, with no turnover covered by patents and a large number of process innovators. This cluster has the lowest value for the indicator of innovation opportunities, with a very low proportion of firms receiving funding from EU institutions and a below-average turnover of new products as a share of total turnover.

The innovation pattern in the sectors in this cluster can be labelled as non-competitive widespread innovation: innovation is a part of the business strategies of a large proportion of firms, although there is no high competition for being ahead of other firms and explore the benefits of innovation, since the commercial importance of innovation is relatively small. The lack of competition is confirmed by the low importance attached to advanced process innovation, and in particular, to patent the innovations.

The innovation in this cluster is mainly embodied. Firms belonging to the sectors in this cluster tend to spend relatively more in machinery and equipment and relatively less in $R \& D$ than sectors in other clusters.

Cluster 3 includes five manufacturing industries and one service industries (ComputerRelated Activities) ${ }^{7}$. The level of innovation opportunities in this cluster is relatively high, with the highest turnover of new products as a share of total turnover. The levels of outputoriented innovation and the level of advanced process innovation are also above average. The characteristics of this cluster are related to an output-competitive innovation: a relatively high number of firms develop new products that are important in terms of the sectoral turnover. Innovation is aimed at securing a market share in the innovative products market, that is, in the innovation outputs market. Firms rely on the complexity of design, long term advantage and structural changes to secure their market share.

This type of innovation in this cluster tends to be embodied, with low reliance on internal sources of knowledge, reflecting the orientation of innovation towards the creation of marketable outputs, rather than the development of advanced knowledge.

Cluster 4 contains six manufacturing industries. This cluster shows a highly above-average indicator of advanced process innovation, with the lowest share of process innovators and the highest share of turnover covered by patents. The level of innovation opportunities in the 
sectors belonging to this cluster is relatively high, mainly due to the importance of EU funding, but the importance of output-oriented innovation is low, which means that a relatively small number of product innovators take advantage of the innovation opportunities available.

Innovation in this cluster is concentrated on a relatively few number of firms and can be labelled as input-competitive innovation: a small proportion of firms rely on their technological position to secure the benefits of innovation (sales of new products). This technological position is determined by the quality of innovation inputs used, that is, the stock of knowledge and the innovation potential possessed by the firm, which lead to the creation of technology barriers for the decision to innovate of other firms.

This type of innovation is clearly disembodied, which reflects the fact that technologically advanced and competitive innovation requires highly specialized activities, mainly achieved by expenditure in $R \& D$ and whose effectiveness depends on reliance on internal sources of knowledge.

It is worth noting that this cluster includes three highly standardised, low-tech sectors: Wood and Cork, Leather and Footwear and Wearing Apparel. Contrary to prior expectations, there seems to exist a strong tendency for the few firms innovating in these sectors to seek and secure technological advantage over the other firms. In fact, Wood and Cork is one of the sectors with higher proportion of patented output and it shows above average use of disembodied forms of innovation and knowledge from competitors and customers. Wearing Apparel has one of the highest proportions of patented output and Leather and Footwear has the highest proportions of firms seeking knowledge from universities.

These findings might be explained by the fact that these sectors are the ones in which Portugal traditionally holds an international competitive advantage, a position that is currently threatened by the process of economic globalization and increasing demands from the world market for quality and innovative products. For these reason, technological advances have became are a major component on the competitive strategies of leading companies in this sector to secure their share in the world market.

Overall, the patterns of technological competition in Portuguese industries are defined by the coexistence of high level of innovation opportunities and a tendency to secure the benefits of innovation. In economic terms, this is equivalent to a strong demand for innovation and a tendency of the suppliers of innovation (the firms that innovate) to secure their market share 
in innovation sales or their share on available public funding.

High levels of technological competition appear both in industries with relatively high level of innovation diffusion (Cluster 3) and in sectors where innovation activities are concentrated in a small set of firms (Cluster 4). In first case, the firms develop innovation strategies oriented to the output, mainly using external resources and in the second case competition is based on the input side of the innovation, through the use of internal resources.

Lower levels of technological competition occur when the demand for innovation is relatively low and the suppliers do not show a strong tendency to protect the benefits of the innovation. This can occur when the innovation is widespread diffused within the sector (Cluster 2) or when the dominant type of innovation is process innovation, which is not directly linked to commercial results (Cluster 1).

Also, high levels of technological intensity seem to imply high levels of technological competition. With the exception of Machinery and Equipment (see note 5), all the sectors classified as high-tech in the OECD taxonomy (OECD 1997) belong to clusters classified here as competitive in terms of technological strategies. In opposition, low levels of technological competition occur in most of the service industries. The only exception is the sector of Computer-related Activities, a fact which may be explained by the relatively high level of market competition in this industry.

It is also found that patterns of high diffusion of process innovation tend to occur in contexts of few innovation opportunities (Cluster 1 and Cluster 2). However, patterns of high diffusion of product innovation are observed both in contexts of many innovation opportunities (Cluster 3 ) and few innovation opportunities (Cluster 2). In the first case, the diffusion reflects a high degree of technological competition over those opportunities, while in the second case it reflects the widespread acceptance of innovation practices across the firms in the sector. In both cases, product innovation diffusion is accompanied with an option for embodied innovation ${ }^{8}$.

\section{Innovation diffusion, technological competition and innovation environment}

According to the technological regime/technological trajectory literature, the sectoral patterns of innovation diffusion and technological competition are determined by characteristics specific to the sector- what we can call the "sectoral innovation environment". This section tests whether the clusters of innovation patterns are both distinct and internally homogeneous 
when considering those determinants. We assume that the innovation environment can be assessed by the perceived obstacles to innovation and the industries' structural characteristics.

\subsection{Inter-cluster heterogeneity}

This sub-section tests whether the clusters found are associated with substantially different environments, by identifying the innovation environments associated with each of the innovation patterns found.

For this analysis, we consider the following indicators, calculated from the CIS data:

a) Variables on the industries' structural characteristics: sectoral average turnover, percentage variation of the sectoral turnover (1998-2000), percentage of firms whose turnover increased by $10 \%$ or more, percentage of firms whose turnover decreased by $10 \%$ or more, investment as a share of sectoral turnover, variation of exports relative to variation of sectoral turnover and sectoral average productivity (defined as turnover per employee).

b) Variables on the factors hindering innovation: percentage of firms reporting the following factors as a very serious obstacle to innovation: economic risks, innovation risks, sources of finance, organisational rigidities, lack of qualified personnel, lack of information on technology, lack of information on markets and lack of customer responsiveness.

The questions in the CIS questionnaire related to the obstacles to innovation are answered by both the firms that innovate and the firms that did not innovate. As such, this information provides a good indicator of the overall obstacles hindering innovation in an industry, including both the obstacles to the decision to innovate and to particular innovation strategies.

It should be noticed that productivity is here considered as a determinant of the sectoral innovation patterns, instead of one of its effects (e.g. Kleinknecht and Mohnen (2002)).

In order to separate the influence of the structural characteristics on the obstacles to innovation, a factor analysis is performed on those two sets of indicators. This analysis uses the same methods applied in the last section. Five major principal components were extracted (Table 4), explaining $67 \%$ of the variance in the variables chosen. The values of the overall KMO (0.46) and most of the individual KMO and communalities are satisfactory. 
Table 4: Innovation environment (factor analysis)

\begin{tabular}{|c|c|c|c|c|c|c|c|}
\hline & $\begin{array}{c}\text { Factor A } \\
\text { (org/info) }\end{array}$ & $\begin{array}{c}\text { Factor B } \\
\text { (risks) }\end{array}$ & $\begin{array}{c}\text { Factor C } \\
\text { (dimension) }\end{array}$ & $\begin{array}{c}\text { Factor D } \\
\text { (shift to exp) }\end{array}$ & $\begin{array}{c}\text { Factor E } \\
\text { (vitality) }\end{array}$ & KMO & Comm. \\
\hline Average turnover & -0.23 & -0.25 & 0.88 & -0.08 & 0.02 & 0.43 & 0.90 \\
\hline Variation of turnover & -0.04 & -0.30 & 0.01 & -0.62 & 0.20 & 0.52 & 0.52 \\
\hline Turnover increased by $10 \%$ & -0.05 & -0.54 & 0.02 & 0.31 & 0.25 & 0.14 & 0.45 \\
\hline Turnover decreased by $10 \%$ & 0.22 & -0.02 & -0.13 & 0.31 & -0.53 & 0.34 & 0.44 \\
\hline Investment / turnover & 0.11 & 0.05 & -0.09 & 0.00 & 0.85 & 0.26 & 0.74 \\
\hline Var. exports / var. turnover & -0.17 & -0.12 & -0.20 & 0.66 & 0.01 & 0.12 & 0.52 \\
\hline Turnover / employees & -0.16 & -0.05 & 0.91 & -0.18 & -0.04 & 0.38 & 0.90 \\
\hline Obstacle: economic risks & 0.04 & 0.52 & -0.09 & 0.10 & 0.29 & 0.75 & 0.37 \\
\hline Obstacle: innovation risks & 0.14 & 0.86 & 0.01 & 0.09 & 0.07 & 0.47 & 0.78 \\
\hline Obstacle: sources of finance & -0.06 & 0.88 & -0.23 & 0.06 & -0.03 & 0.46 & 0.83 \\
\hline Obstacle: org.rigidities & 0.58 & -0.07 & 0.52 & 0.45 & 0.00 & 0.56 & 0.81 \\
\hline Obstacle: qualified personnel & 0.74 & 0.15 & 0.19 & 0.36 & -0.12 & 0.59 & 0.75 \\
\hline Obstacle: info on technology & 0.86 & 0.00 & -0.22 & -0.13 & 0.12 & 0.62 & 0.82 \\
\hline Obstacle: info on markets & 0.82 & 0.02 & -0.15 & -0.10 & -0.15 & 0.62 & 0.73 \\
\hline Obstacle: custm. Responsiveness & 0.71 & 0.07 & -0.16 & -0.10 & 0.06 & 0.59 & 0.55 \\
\hline Eigenvalue & 3.42 & 2.38 & 1.71 & 1.50 & 1.10 & & \\
\hline Prop. of variance explained & 0.23 & 0.16 & 0.11 & 0.10 & 0.07 & & \\
\hline Cumul. prop. of variance expl. & 0.23 & 0.39 & 0.50 & 0.60 & 0.67 & & \\
\hline
\end{tabular}

The first factor explains $23 \%$ of the total variance and covers the indicators of market, organization and information obstacles to innovation: organizational rigidities, qualified personnel, information on technology, information on markets and customer responsiveness.

Factor B explains $16 \%$ of the total variance and shows a high negative factor load on the percentage of firms whose turnover increased by more than $10 \%$ and a high positive factor load on the obstacles related to risk and finance: economic risks, innovation risks and sources of finance. Overall, this factor seems to be related to risks and financial obstacles.

Factor $\mathrm{C}$ represents $11 \%$ of the total variance and relates to the dimension of the sector, aggregating average turnover, average productivity and organizational rigidities.

Factor D accounts for $10 \%$ of the total variance and shows a high negative load on the variation of turnover and a high positive load on the variation of exports as a share of the variation of turnover. This factor seems to represent shift to exports as a solution for overcoming decreasing sectoral average turnover.

Factor E explains $7 \%$ of the variance and shows a high positive load on investment as a proportion of sectoral turnover and a high negative load on the percentage of firms whose 
turnover decreased by more than $10 \%$. This factor is then related to the vitality of the sector.

The obstacles to innovation do not seem to be strongly correlated with the industries' structural characteristics, as only two of the principal components extracted combine indicators from both sets of variables. However, the composition of variables in factor B suggests that at the industry level, the lack of innovation risks and financial impediments to innovation is more closely associated with the existence of a subset of fast-growing firms than with the sectoral average variation of turnover.

In Table 5 and Figure 3 we characterize the clusters of innovation patterns found in the last section according to the factors extracted for the new set of variables.

The most relevant characteristic of Cluster 1 (non-competitive process innovation) is a high degree of vitality, mainly due to an above-average level of investment as share of turnover.

Cluster 2 (non-competitive widespread innovation) shows the highest indicator of vitality, size and productivity and the lowest indicator for both kinds of perceived obstacles to innovation.

Cluster 3 (output-competitive innovation) has a below-average level of vitality, mainly due to a below-average level of investment as share of turnover and an above average indicator of shift to exports, with low variation of turnover and high variation of exports in relation to the variation of turnover. Size and productivity are below the whole dataset average and perceived obstacles to innovation are relatively low.

Finally, Cluster 4 (input-competitive innovation) shows the highest level of reported market, organization and information problems and the lowest indicators of vitality (due to a below average level of investment). 
Table 5: Innovation patterns (characterization in terms of innovation environment)

\begin{tabular}{|c|c|c|c|c|c|}
\hline & $\begin{array}{c}\text { All } 35 \\
\text { sectors }\end{array}$ & $\begin{array}{c}\text { Cluster } 1 \\
\text { (n-comp proc.) }\end{array}$ & $\begin{array}{c}\text { Cluster } 2 \\
\text { (n-comp) }\end{array}$ & $\begin{array}{c}\text { Cluster } 3 \\
\text { (output-comp) }\end{array}$ & $\begin{array}{c}\text { Cluster } 4 \\
\text { (input-comp) }\end{array}$ \\
\hline Factor A: Market, org. and info. problems & 0 & 0 & -0.86 & -0.26 & 0.77 \\
\hline Factor B: Risks and financial problems & 0 & 0.14 & -0.47 & -0.36 & -0.01 \\
\hline Factor C: Size and productivity & 0 & 0.13 & 0.45 & -0.41 & -0.28 \\
\hline Factor D: Shift to exports & 0 & -0.08 & 0.29 & 0.58 & -0.06 \\
\hline Factor E: Vitality & 0 & 0.22 & 0.69 & -0.42 & -0.47 \\
\hline Average turnover & 27858.73 & 25299.63 & 93387.50 & 11981.72 & 9665.27 \\
\hline Variation of turnover & 0.44 & 0.28 & 0.55 & 0.14 & 0.12 \\
\hline Turnover increased by $10 \%$ & 0.03 & 0.02 & 0.09 & 0.03 & 0.02 \\
\hline Turnover decreased by $10 \%$ & 0.02 & 0.01 & 0.01 & 0.04 & 0.02 \\
\hline Investment / turnover & 0.11 & 0.13 & 0.1 & 0.08 & 0.07 \\
\hline Variation exports / variation turnover & 0.52 & 0.18 & 0.1 & 1.80 & 0.52 \\
\hline Turnover / employees & 200.42 & 257.02 & 250.77 & 116.93 & 75.89 \\
\hline Obstacle: economic risks & 0.22 & 0.22 & 0.34 & 0.19 & 0.23 \\
\hline Obstacle: innovation risks & 0.37 & 0.37 & 0.32 & 0.31 & 0.35 \\
\hline Obstacle: sources of finance & 0.29 & 0.29 & 0.22 & 0.26 & 0.3 \\
\hline Obstacle: organisational rigidities & 0.09 & 0.09 & 0.08 & 0.08 & 0.1 \\
\hline Obstacle: qualified personnel & 0.17 & 0.18 & 0.06 & 0.16 & 0.23 \\
\hline Obstacle: information on technology & 0.08 & 0.08 & 0.01 & 0.08 & 0.14 \\
\hline Obstacle: information on markets & 0.07 & 0.05 & 0.03 & 0.06 & 0.11 \\
\hline Obstacle: customer responsiveness & 0.09 & 0.09 & 0.03 & 0.07 & 0.16 \\
\hline
\end{tabular}

Mean values and standard deviations (in brackets)

The characterization above suggests that high levels of technological competition (Cluster 3 and Cluster 4) tend to occur in sectors where firms have lower than average size and productivity and in contexts of relatively low levels of vitality.

In Cluster 4, these factors, together with the significance of market, organization and information problems imply a small ability for the individual firms to engage in innovation activities, which means a small level of diffusion of innovation. The small number of innovative firms, together with the availability of innovation opportunities, generate a high level of technological competition.

In Cluster 3, low vitality and productivity is balanced against low perceived obstacles to innovation and a sectoral tendency to shift output to the export market, where the market competition for new products is higher. This market pressure may force the firms in this cluster to introduce new products as well. The level of innovation diffusion in this case is relatively high. In this case, market pressure and importance of innovative sales in terms of commercial sales create a high level of technological competition. 
Non-competitive patterns of technological competition (Cluster 1 and Cluster 2) tend to occur in sectors with relatively high size and productivity and in contexts of high sectoral vitality.

These factors contribute to a high ability for the firms to engage in innovation activities, which may explain the high proportion of firms engaging in innovation activities (in cluster 1, limited to process innovation), resulting in a high level of diffusion of innovations. In both cases, due to the relative unimportance of innovative sales (that is, small level of innovation opportunities in terms of output), firms do not have incentives to protect the benefits of their innovation, resulting in a relatively low level of technological competition.

It is worth noting that the clusters with relatively low perceived obstacles to innovation (Cluster 2 and Cluster 3) are also the ones with higher levels of product innovation diffusion and with higher tendency to shift output to exports.

Figure 3: Innovation patterns (characterization in terms of innovation environment)

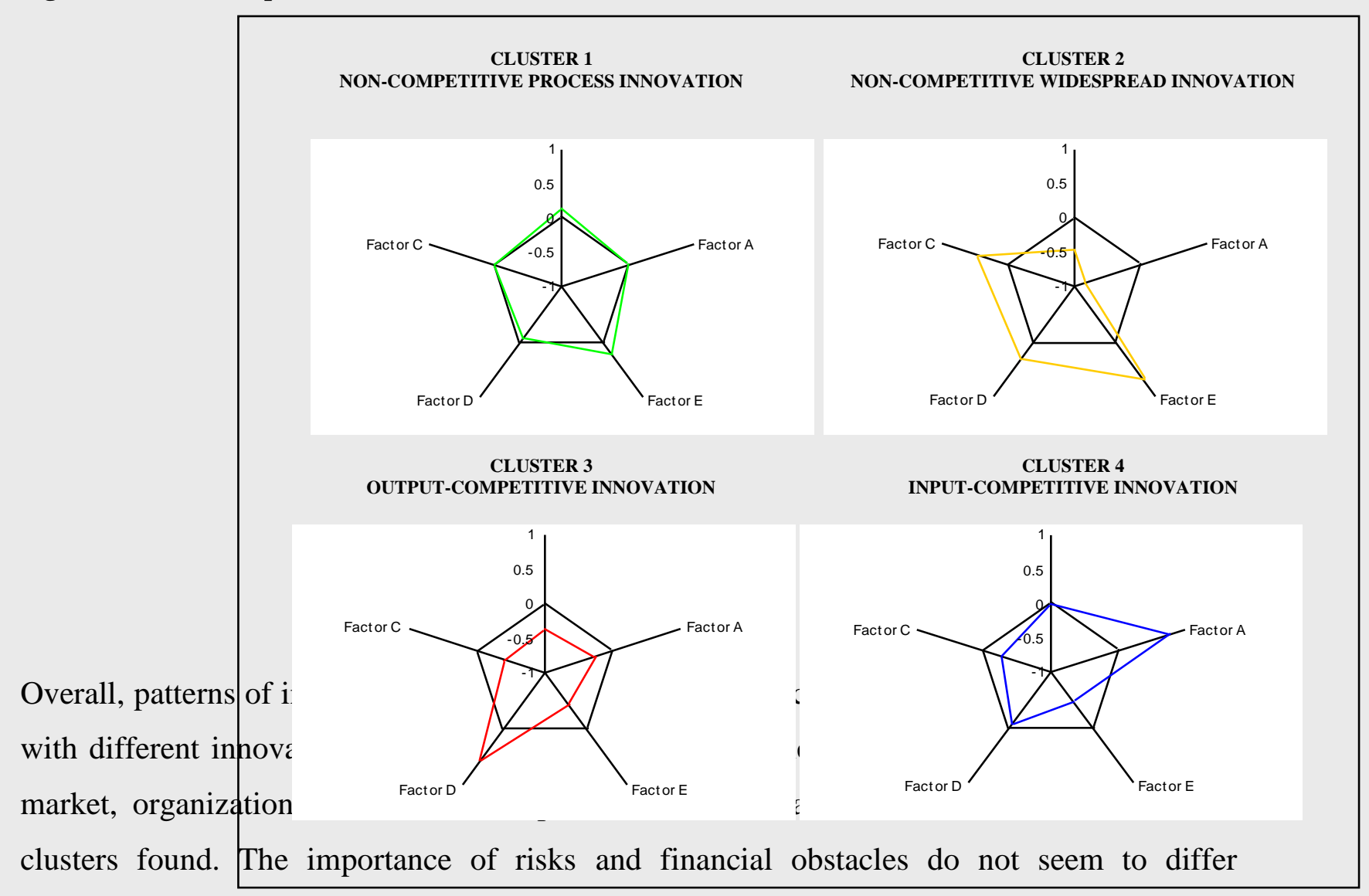
substantially across the four clusters.

\subsection{Intra-cluster heterogeneity}

In the last section, the characterization of the innovation pattern clusters was based on the 
average values for those clusters of the variables and principal components regarding innovation environment. We now proceed to investigate whether the individual sectors within each of the clusters are associated with substantially different innovation environments.

We first group the sectors in a second cluster structure, based on the principal components derived from the factor analysis to the set of variables on the innovation environment. The clustering methods used are the same as in Section 4.

Preliminary performances of the clustering algorithms identified three outliers in the dataset, featuring extreme value for some variables, when comparing to the dataset average. These are the Electricity and Gas Supply, Water Distribution and Fabricated Metals industries ${ }^{9}$. The outliers were removed on posterior performances of the clustering algorithm. The final clustering structure has 4 clusters. The cluster membership and characteristics are presented in Table 6 and Table 7.

Table 6: Innovation environment (cluster membership)

\begin{tabular}{cc}
\hline & Sectors \\
\hline Cluster A & $\begin{array}{r}\text { Chemicals, Machinery and equipment, Electrical machinery, Radio/TV and telecommunication } \\
\text { equipment, Motor vehicles, Recycling, Financial intermediation, Insurance, Finance-related, } \\
\text { Computer-related activities, Other business activities }\end{array}$ \\
\hline Cluster B & Other mining, Pulp and paper, Transport-related and travel, Post and Telecommunications \\
\hline Cluster C & $\begin{array}{c}\text { Food and beverages, Textiles, Wearing apparel, Leather and footwear, Wood and Cork, Publishing } \\
\text { and printing, Rubber and Plastics, Non-metallic minerals, Medical and precision instruments, Other } \\
\text { transport equipment, Furniture, Wholesale }\end{array}$ \\
\hline Cluster D & Basic metals, Office machinery and computers, Land transport, Water transport, Air transport \\
\hline
\end{tabular}


Table 7: Innovation environment (cluster characterization)

\begin{tabular}{|c|c|c|c|c|c|}
\hline & All 35 & Cluster A & Cluster B & Cluster C & Cluster D \\
\hline \multirow{2}{*}{ Factor A: Org. and information problems } & \multirow{2}{*}{0} & -0.46 & -0.07 & 1.06 & -1.06 \\
\hline & & $(0.5)$ & $(0.98)$ & $(0.6)$ & $(0.55)$ \\
\hline \multirow{2}{*}{ Factor B: Risks and financial problems } & \multirow{2}{*}{0} & -0.61 & -0.16 & 0.16 & 1.49 \\
\hline & & $(0.71)$ & $(0.8)$ & $(0.46)$ & $(1.15)$ \\
\hline \multirow{2}{*}{ Factor C: Size and productivity } & \multirow{2}{*}{0} & -0.08 & 0.01 & -0.13 & -0.29 \\
\hline & & $(0.78)$ & $(0.22)$ & $(0.29)$ & $(0.09)$ \\
\hline \multirow{2}{*}{ Factor D: Shift to exports } & \multirow{2}{*}{0} & -0.04 & -0.27 & 0.00 & 0.21 \\
\hline & & $(0.7)$ & $(0.31)$ & $(0.49)$ & $(0.11)$ \\
\hline \multirow{2}{*}{ Factor E: Vitality } & \multirow{2}{*}{0} & -0.55 & 2.13 & -0.26 & 0.07 \\
\hline & & $(0.71)$ & $(0.64)$ & $(0.38)$ & $(0.93)$ \\
\hline Average turnover & 27858.73 & 36157.58 & 30236.62 & 4810.83 & 5542.98 \\
\hline Variation of turnover & 0.44 & 0.28 & 0.49 & 0.18 & 0.25 \\
\hline Turnover increased by $10 \%$ & 0.03 & 0.04 & 0.04 & 0.02 & 0.01 \\
\hline Turnover decreased by $10 \%$ & 0.02 & 0.03 & 0.00 & 0.02 & 0.00 \\
\hline Investment / turnover & 0.11 & 0.07 & 0.29 & 0.09 & 0.08 \\
\hline Variation exports / variation turnover & 0.52 & 0.30 & 0.28 & 0.32 & 0.34 \\
\hline Turnover / employees & 200.42 & 181.69 & 124.78 & 87.13 & 106.18 \\
\hline Obstacle: economic risks & 0.22 & 0.14 & 0.24 & 0.24 & 0.37 \\
\hline Obstacle: innovation risks & 0.37 & 0.26 & 0.37 & 0.40 & 0.57 \\
\hline Obstacle: sources of finance & 0.29 & 0.18 & 0.23 & 0.32 & 0.57 \\
\hline Obstacle: organisational rigidities & 0.09 & 0.07 & 0.10 & 0.13 & 0.03 \\
\hline Obstacle: qualified personnel & 0.17 & 0.13 & 0.16 & 0.28 & 0.07 \\
\hline Obstacle: information on technology & 0.08 & 0.04 & 0.09 & 0.14 & 0.03 \\
\hline Obstacle: information on markets & 0.07 & 0.04 & 0.03 & 0.13 & 0.01 \\
\hline Obstacle: customer responsiveness & 0.09 & 0.06 & 0.06 & 0.15 & 0.05 \\
\hline
\end{tabular}

Mean values and standard deviations (in brackets)

The sectors in Cluster A are mainly characterized by relatively low levels of vitality and low levels for all types of perceived obstacles to innovation. Cluster B has the highest value for the indicators of vitality and a below-average indicator of shift to exports and risks and financial problems. Cluster $\mathrm{C}$ is characterized by high levels for all types of perceived obstacles to innovation (especially market, organization and information problems) and below average indicators for vitality and size/productivity. Finally, cluster D shows an extremely high level of risks and financial obstacles and an extremely low value for the factor related to market, organization and information problems. This cluster also shows the lowest value for the indicator of size and productivity and the highest indicator of shift to exports.

In short, cluster $\mathrm{B}$ is characterized by a high ability to innovate and cluster $\mathrm{C}$ shows a low ability to innovate. In Cluster A, ability to innovate is hampered by low sectoral vitality and in 
Cluster D ability to innovate is hampered by risks and financial problems but balanced by a strong pressure to innovate exerted by the competition in the exports market and by low relevance of market, organizational and information problems.

The comparison of the cluster structure obtained using variables related to the innovation environment with the one obtained using variables related to innovation patters shows a considerably high degree of intra-cluster heterogeneity for two of the clusters:

The sectors in Cluster 1 (non-competitive process innovation) are distributed across the four innovation environment clusters. In particular, the firms in the sectors of Cluster 1 that belong to Cluster A and Cluster C may have a lower ability to innovate than other sectors in Cluster 1. In the first case, this is due to a lower level of vitality, comparing with the cluster average. In the second case, it is due to a lower level of vitality and a higher importance of market, organization and information risks.

The sectors in Cluster 2 (non-competitive widespread innovation) are distributed across Cluster A, B and D. The Financial Intermediation and Insurance sectors, in Cluster A, will probably have a lower level of ability to innovate than firms in the other two clusters, due a lower level of vitality.

The sectors in Cluster 3 (output-competitive innovation) belong to Cluster A, with the exception of the Furniture industry. Therefore, there is a high degree of homogeneity within the sectors in Cluster 3 regarding innovation environments. The distinctive average characteristics of that cluster (low vitality, size and productivity and low relevance of obstacles to innovation) are observed for most of the individual sectors.

The sectors in Cluster 4 (input-competitive innovation) belong to Cluster C, with the exception of Radio, TV and Telecommunication, in Cluster A. This homogeneity confirms the relevance of low levels of vitality and perceived obstacles to innovation.

In short, the clusters classified as patterns of high technologic competition (Cluster 3 and Cluster 4) are more internally homogeneous than the clusters classified as patterns of low technological competition (Cluster 1 and 2).

\section{Discussion}

The analysis in this paper assumed that within an industry all firms are exposed to the same innovation environment and the firms that decide to innovative follow the same innovation 
strategies. This assumption may not be valid when there is a high degree of heterogeneity within the industry in terms of firms' size or markets served. In particular, the hypothesis that firms within the same industry follow different innovation strategies is consistent with findings from strategic management studies in other areas of firms' behaviour (Porter 1980). A series of recent studies have indeed shown that innovation patterns do not match with industry classifications (e.g. Arvanitis and Hollenstein (2001), Hollenstein (2003), Leiponen and Drejer (2005)).

The definition of patterns of technological competition at the industry level must also take into account that firms in an industry may not compete in the same innovation output market. Furthermore, some firms may operate in multiple industries. Innovation patterns may therefore not be defined at the industry level but across markets or strategic groups.

For these reasons, the study of inter-sectoral heterogeneity in the levels of technological competition and innovation diffusion should be complemented with studies on intra-sectoral heterogeneity, using data at firm-level.

The analysis could also be improved by considering the temporal dimension of the patterns of innovation diffusion and technological competition. In fact, a full characterization of these patterns as a dimension of the industries' technological trajectories should include the effects that changes in the innovation environment have over the firms' decision to innovate and innovation strategies. This would require time-series innovation data, which at the moment is limited to the three Portuguese CIS surveys.

\section{Conclusions and policy implications}

There are four distinctive innovation patterns of innovation diffusion and technological competition in Portuguese manufacturing and service industries. Patterns of high technological competition are characterized by a strong demand for innovation and a tendency of the innovative firms to gain and secure technological/innovation advantage in order to secure their market share in innovation sales.

Given the inter-industry heterogeneity in innovative patterns, selective technological policies directed at the industries following each pattern should identify what should be stimulated in those industries in order to maximize the benefits of innovation for society as a whole.

The cluster classified as output-competitive (cluster 3) shows an output-oriented innovation, 
with numerous product innovators. There are also many opportunities for the commercialization of innovation output. According to some authors (e.g. Edquist et al 2002) these are the innovation characteristics that most contribute to employment generation. These sectors should then receive particular attention and be the target of increased public resources. This could also increase the level of technological competition among firms in these sectors, since they tend to have relatively low levels of investment, which reduce the firms' ability to engage in innovation.

In the cluster classified as input-competitive innovation (Cluster 4), the number of product innovators is small but there is a high degree of technological competition. Innovation in these sectors is mainly disembodied. This type of innovation generates knowledge that might be also useful in other sectors of the economy. For this reason, technological policies in these sectors should aim at increasing the level of innovation diffusion, which seems to be limited by market, organization and information obstacles.

The clusters classified as non-competitive (Cluster 1 and Cluster 2) face a relatively low demand for innovative output and are characterized by a small degree of technological competition. However, firms in both clusters have a relatively high ability to innovate, as judged by the level of sectoral investment and the relative unimportance of market, organizational and information problems. Suitable technological policies for Cluster 2 would have a market-pull dimension, aiming at increasing the demand for innovative products, which would lead to an increase in the firms' innovative effort. In cluster 1, where only process innovation is widespread diffused, market-pull policies would probably be less relevant than technology-push policies, aiming at improving the firms' innovation activities, especially in disembodied form.

The conclusions and policy implications of this study should consider, however, that the introduction of selective technological policies must be based on information on a wide range of factors apart from the levels of innovation diffusion and technological competition. In particular, information is required on the interdependences between industries and the role of positive externalities, in order to identify the sectors where innovation generates more social benefit. Also, it is crucial to complement the analysis of the inter-sectoral heterogeneity in innovation diffusion and technological competition with the study of intra-sectoral heterogeneity in the firms' innovation behaviour. 


\section{References}

Arvanitis, S., Hollenstein, H. (2001). Innovative activity and firm characteristics. A cluster analysis of Swiss manufacturing using firm-level data, in "OECD, Innovative Networks: Co-operation in National Innovation Systems.” OECD, Paris, 48-76.

Audretsch, D B. (1997) Technological regimes, industrial demography and the evolution of industrial structures. Industrial and Corporate Change 6, 49-82.

Castellacci, F. (2004) How innovation differs across sectors in Europe? Evidence from the CIS-SIEPI database. Working Paper, Centre for Technology, Innovation and Culture, University of Oslo.

Cefis, E., Orsenigo, L. (2001) The persistence of innovative activities: a cross countries and cross-sectors comparative analysis. Research Policy 30 (7), 1139-1158.

Cohen, W.M., Nelson, R R., Walsh, J P (2002) Links and impacts: the influence of public research on industrial R\&D. Management Science 48 (1), 1-23.

Coombs, R., Miles, I. (2000) Innovation, measurement and services: the new problematique., in Innovation Systems in the Service Sectors. Measurement and Case Study Analysis., S J Metcalfe, I Miles (Eds.), Kluwer Academic Publishers, Boston., Dordrecht, London, 85-104.

Dosi, G. (1982) Technological paradigms and technological trajectories: a suggested interpretation of the determinants and directions of technical change. Research Policy 11 (3), 147-162.

Edquist, C., Hommen, L., McKelvey, M. (2002) Innovations and Employment: Product versus Process Innovation. Edward Elgar, Cheltenham, UK.

Evangelista, R., Sirilli, G. (1995) Measuring innovation in services. Research Evaluation 5, 207-215.

Evangelista, R. (1999) Knowledge and Investment. The Sources of Innovation in Industry. Edward Elgar, Cheltenham.

Evangelista, R. (2000): "Sectoral patterns of technological change in services", Economics of Innovation and New Technologies 9 (3), 183-221.

Gallouj, F. (1999) Les trajectoires de l'innovation dans les services: vers un enrichissement des taxonomies évolutionnistes, Économies et Sociétés. Série Économie et Gestion des Services (EGS) 1, 143-169.

Hollenstein, H. (2003) Innovation modes in the Swiss service sectors: a cluster analysis based on firm-level data. Research Policy 32, 845-863.

Kaiser, H F. (1958) The Varimax criterion for analytical rotation in factor analysis. Psychometrika 23, 187200.

Kleinknecht, A., Mohnen, P. (2002) (eds.) Innovation and firm performance: Econometric explorations of survey data. Palgrave, Basingstoke.

Kleinknecht, A., Oostendorp, R. (2002) R\&D and export performance: Taking account of simultaneity., in Kleinknecht and Mohnen (2002), 310-320.

Klevorick, A., Levin, R., Nelson, R R., Winter, S.G (1995) On the sources and significance of interindustry differences in technological opportunities. Research Policy 24(2), 185-205. 
Kline, S J., Rosenberg, N. (1986) An overview of innovation., in The Positive Sum Strategy: Harnessing Technology for Economic Growth., eds. R Landau, N Rosenberg., National Academy Press, Washington.

Klomp, L. (2001) Measuring output from R\&D activities in innovation surveys, Paper presented at the ISI 53 conference, Statistics Netherlands.

Leiponen, A., Drejer, I. (2005) Technological regimes and strategy: intraindustry heterogeneity in the organization of innovation activities. Paper submitted to the DRUID Tenth Anniversary Summer Conference 2005 on Dynamics of Industry and Innovation: Organizations, Networks and Systems.

Malerba, F. (2002) Sectoral systems of innovation and production. Research Policy, 31 (2), 247-264.

Malerba, F., Orsenigo, L. (2000) Knowledge, innovative activities and industrial evolution, Industrial and Corporate Change 9(2), 289-314.

Nascia, L., Perani, G. (2002) Diversity of innovation in Europe. International Review of Applied Economics 16(3), 277-293.

Nelson, R., Winter, S. (1977) In search of a useful theory of innovation. Research Policy 6 (1), 36-76.

Nelson, R., Winter, S. (1982) An Evolutionary Theory of Economic Change. The Belknap Press of Harvard University Press, Cambridge, USA.

OECD (1996) Innovation, Patents and Technological Strategies. OECD, Paris.

OECD (1997) Revision of the high-technology sector and product classification, STI Working Paper Series 1997/2. OECD, Paris.

Pavitt, K. (1984) Sectoral patterns of technical change: towards a taxonomy and a theory. Research Policy 13 (6), 343-373.

Pavitt, K., Robson, M., Townsend, J. (1989) Technological accumulation, diversification and organisation of technological activities in UK companies, 1945-1983. Management Science 35(1), 81-99.

Peters, L., Swinnen, G., Tiri, M. (2004) Patterns of innovation in the Flemish business sector- a multivariate analysis of CIS-3 firm-level data. IWT-Studies \#47. IWT Observatory, Brussels.

Pianta, M. (2000) The employment impact of product and process innovations. in The employment impact of innovation: evidence and policy, M. Vivarelli and M. Pianta (Eds.), Routledge, London.

Porter, M E. (1980) Competitive Strategy. New York: Free Press, New York.

Sellenthin, M., Hommen, L. (2002) How innovative is Swedish industry? A factor and cluster analysis of CIS II. International Review of Applied Economics, 16 (3), 319-331.

Veugelers, R., Cassiman, B. (1999) Make and buy in innovation strategies: evidence from Belgian manufacturing firms, Research Policy 28 (1), 63-80.

Winter, S G. (1984) Schumpeterian competition in alternative technological regimes. Journal of Economic Behavior and Organization 5 (2), 287-320.

Notes

${ }^{1}$ The KMO measures the degree of homogeneity of the variables within a factor. 
${ }^{2}$ The communality of a variable in a factor model represents the proportion of its variance which is shared with the other variables via the common factors.

${ }^{3}$ It can also be argued (Peters et al 2004) that "Make" and "Buy" are not substitutes once we consider a third option, "Co-operate". However, in the present analysis, the percentage of firms engaged in cooperation agreements is not included in the same principal component as the expenditures in R\&D and machinery and equipment, suggesting that for Portuguese firms, "Cooperate" is not correlated with either "Make" or "Buy" innovation strategies.

${ }^{4}$ In the sector of Office Machinery and Computers nearly $100 \%$ of the firms have engaged in product innovation, process innovation, cooperation and structural changes. This sector also shows highly above-average relative expenditure in $\mathrm{R} \& \mathrm{D}$ and indicators of strategic protection of innovations and highly below-average share of expenditure in machinery. Water Distribution has an extremely high turnover from new products as a share of total turnover and extremely high level of EU funding. Rubber and Plastics has a very high proportion of turnover covered by patents.

${ }^{5}$ The Machinery and Equipment industry, although highly product innovative in nature, shows for the Portuguese case a lower than average proportion of product innovators and a higher than average proportion of process innovators and is thus classified in cluster 1.

${ }^{6}$ It should be noticed that the extent of product innovation in the Financial Intermediation and Insurance sectors is dependent on the definition of what is a new product, as viewed by the respondents of the survey. The launching of a new investment fund, hedge fund or financial derivative might be considered as the creation of a new financial product, even when it does not differ very substantially from what already exists in the market. Therefore, the proportion of product innovators in these sectors may be overestimated by the survey.

${ }^{7}$ Although its products are highly standardized, the sector of Fabricated Metals belongs to Cluster 3 and not to Cluster 1 , due to relative unimportance of process innovation and the relevance of factors related with product innovation (e.g. structural changes in the firm).

${ }^{8}$ This result does not conflict with the belief on the association of intensity of product innovation and proportion of innovation expenditures in $\mathrm{R} \& \mathrm{D}$, as derived from Pavitt's taxonomy. The percentage of product innovators in an industry is not considered in this study as an indicator of the relative importance of product innovation (versus process innovation) in terms of share in total innovation expenditure in the industry, but instead as a measure of the level of diffusion of product innovation within that industry.

9 The Electricity and Gas Supply industry shows extremely high average turnover and average productivity; Water Distribution shows extremely high variation of turnover and high average productivity and Fabricated Metals shows a marked tendency of shift to exports, with low variation of turnover and extremely high variation of exports as variation of turnover). 